\title{
НІМЕЦЬКОМОВНИЙ ГЕНЕРАЦІЙНИЙ РОМАН ЯК ЖАНРОВИЙ РІЗНОВИД СІМЕЙНОГО РОМАНУ
}

\section{Ольга Гречешнюк}

\author{
Львівський національний університет імені Івана Франка, \\ вул. Університетська, 1, м. Львів, Україна, 79000 \\ Hrecheshnyukolya@i.ua
}

\begin{abstract}
Розглянуто проблему трактування генераційного роману як модифікації жанру сімейного роману на прикладі новітньої німецькомовної літератури. Проаналізовано актуальність цього жанрового різновиду та причини його розвитку у німецькомовному суспільстві. Схарактеризовано чинники та передумови жанрових трансформацій класичного німецького сімейного роману, що призводять до утворення нового явища у літературному дискурсі. Наведено зразки літературних текстів, а саме генераційих романів новітньої німецькомовної літератури (У. Тімм, "На прикладі мого брата", А. Гайгер "У нас все добре", М. Марон “Листи Павла", Т. Дюкерс "Небесні тіла", І. Люстігер “Такі ми є”) та виявлено, що зміна форм у літературі відбувається у вигляді узгодження певних жанрових перетворень та соціально-культурного контексту, їхнього системного осмислення, які об'єднуються в єдине, утворюючи новий жанровий різновид - генраційний роман. Дослідження теми грунтується на теоретичних працях М. Бахтіна, А. Фаулера, М. Нойшефера. А. Ассманн, 3. Вайгель та ін.

Ключові слова: сім'я, генераційний роман, сімейний роман, жанр, жанрова модифікація, жанрова трансформація.
\end{abstract}

Вступ. 3 90-х рр. минулого століття та до сьогодні у Німеччині активно зростає інтерес до досліджень сучасних сімейних романів, що тісно пов'язано з прагненням людини осмислити своє минуле та віднайти власну ідентичність. Адже історичні події XX ст. (світові війни, Голокост, націонал-соціалізм), що сколихнули Європу та принесли людям багато страждань і горя, значно вплинули на свідомість кожного. Особливо це відобразилось на свідомості німецького народу: відчуття провини та розуміння неоднозначності всього, що відбувалося стало визначальним не лише для покоління-учасників подій, а й для покоління їхніх дітей та онуків. Наприкінці XX ст. падіння Берлінської стіни та об'єднання Німеччини знаменувало кардинальні зміни політичних та ідеологічних пріоритетів у країні. Виникає нове суспільне явище, а саме посилений інтерес до проблем пам'яті, яке прийнято називати “меморіальним бумом" (Gedächtnisboom). Це означає, що велику увагу приділяють минулому та спогадам, до яких апелюють з метою зцілення та захисту. Адже спогади про пережите стають важливою складовою формування індивідуальної ідентичності, яка, своєю чергою, нерозривно пов'язана з історією власної сім’ї. Тому сімейний наратив знову переживає

(C) Гречешнюк О., 2019 
своє відродження. Письменники все частіше звертаються до жанру сімейного роману, а головними героями їхніх творів стають представники кількох поколінь однієї родини 3 власними переживаннями, власним ставленням до минулого та спільною метою - відновлення забутої чи прихованої сімейної пам'яті та самоствердження власної ідентичності. Саме це і зумовлює логічну появу генераційного роману, як жанрового різновиду сімейного роману, який є об'єктом нашого наукового дослідження. Виникає він на межі XX-XXI ст. як форма “культури спогадів”. Тут зображується історія кількох генерацій однієї сім’ї, які виступають протагоністами не лише сімейної, а й національної історії з власним колективним досвідом та моральними цінностями. Оскільки надається слово кожному поколінню, яке по-своєму тлумачить ті чи інші історичні події, то ключовими у цій праці будуть поняття “генерація”, “покоління”, “пам'ять” та “історія”. Як приклади, можемо навести такі романи німецькомовних письменників на межі XX-XXI ст.: Уве Тімм "На прикладі мого брата" (“Am Beispiel meines Bruders", 2003), Т. Дюкерс "Небесні тіла" ("Himmelskörper”, 2003), М. Марон “Листи Павла” (“Pawels Briefe”, 1999), А. Гайгер “У нас все добре” (“Es geht uns gut”, 2005) та ін. У кожному з цих романів присутні кілька поколінь однієї сім’ї зі своєю історією та своїми таємницями, які причетні до подій Другої світової війни та націоналсоціалістичного минулого Німеччини. У центрі такого твору зображено проблему вини, пам'яті та переборення травматичного минулого німецьким народом. Взагалі, у німецькій літературі культура пам'яті - це відкрите питання щодо різних парадигм теперішнього, яке і розглядається безпосередньо у генераційному романі. Цей жанровий різновид можна зустріти в різних національних літературах, але в даному випадку зосереджується увага на німецькомовній літературі з їі характерними особливостями. Отже, головним завданням цієї наукової розвідки є грунтовний аналіз специфіки цього жанрового різновиду.

Аналіз останніх досліджень і публікацій. Для того аби краще зрозуміти жанрову специфіку генераційного, або, як ще його називають, поколіннєвого роману, слід розглянути останні дослідження, присвячені цій проблемі. Оскільки в такому творі зображується історія роду однієї сім'ї, то стає зрозумілим, що основою для створення генераційного роману є сімейний наратив, який належить до найбільш популярних та традиційних у світовій літературі. Саме тому в літературознавчому дискурсі останніх десятиліть активно постає питання щодо визначення та розмежування понять сімейний та генераційний роман.

Велика кількість дослідників дотримуються думки, що генераційний роман є субжанром сімейного роману. Ця теза виникає у літературознавстві ще на початку ХХ ст. Тут доречно буде згадати М. М. Бахтіна, який у своїй праці “Форми часу і хронотопу в романі” (1975) [5] представив цілісну концепцію сімейного роману та виокремив з нього роман поколінь як такий, що пройшов шлях трансформацій та наділений певними особливостями. Вчений виділив мотив “порушення ідиліі”, сімейного життя, викликаний історичними подіями XIX-XX ст. Згодом таке визначення у літературознавстві отримав термін сімейна хроніка, який надзвичайно швидко завоював прихильність широкої публіки. Найяскравішими прикладами цього жанру є твори Т. Манна “Будденброкки”, Дж. Голсуорсі “Сага про Форсайтів”, Р. М. дю Гара “Сім’я Тібо”, Е. Золя “Ругон-Макари” та ін. 
Дослідник М. Нойшефер у своїій праці “Умовне я. Сім’я, ідентичність й історія в сучасному сімейному романі" ( "Das bedingte Selbst. Familie, Identität und Geschichte im zeitgenössischen Generationenroman”, 2013) також наводить думку про те, що класичний сімейний роман утворює кілька субжанрів: "Роман виховання та роман про батька, в якому головні герої - представники малої сім’ї, в той час як сімейні хроніки або генераційні романи описують цілі покоління великої родини” [28, с. 16]. Іншими словами, до уваги беруться питання щодо сутності інституту сім'ї та взаємозв'язків між іiі членами.

Про генераційний роман у своїх роботах згадує також літературознавець Б. Ян, який запевняє, що “сучасний сімейний роман - це генераційний роман, в якому зображені щонайменше три покоління родини і кожне з власної перспективи” [23, с. 590]. Його трактування підтримують науковиці А. Ассманн та 3. Вайгель. Наприклад, 3. Вайгель у своїй науковій розвідці “Genea-Logik. Tradition und Evolution zwischen Kultur- und Naturwissenschaften” (2006) присвятила цілий розділ аналізу сучасного сімейного роману. Дослідниця віднесла романи Т. Дюкерс "Небесні тіла”, В. Брун “Земля мого батька", С. Ваквіца "Невидима земля” та ін. до жанру сімейного роману, який, за іiі словами, знову “відродився, як вже давно забутий” [29, с. 88].

Науковиця А. Ассманн у своїх дослідженнях неодноразово наголошувала, що в контексті “культури спогадів” у німецькій літературі виокремлюються два жанрові різновиди: “література про батьків”, яка розвивається в 70-80-ті pp. XX ст., та сімейний/генераційний роман, який з'являється наприкінці 90-х рр. XX ст. та до сьогодні користується великою популярністю. Дослідниця стверджує, що саме спогади $\epsilon$ “музою для сучасного генераційного роману” [19, с. 53], а покоління виступають представниками колективного досвіду. У своїй праці “Забуття історії- одержимість історією" ("Geschichtsvergessenheit Geschichtsversessenheit”, 1999) А. Ассман дуже чітко виокремлює особливості сучасного генераційного роману німецькомовної літератури, які відрізняють його від романів інших європейських літератур. Науковиця наголошує, що у такому творі “відбувається “інтимізація” націонал-соціалізму; у ньому детально відтворюється те, що давно хотілося знати; автори наближають до себе страхіття німецької історії настільки, наскільки це можливо" [3]. Отож ми бачимо, що одностайності у висловлюваннях учених щодо визначення поняття генераційного роману немає. Такі розбіжності у дослідженнях науковців зумовлені актуальністю цього жанрового утворення. Це підтверджується великою кількістю художніх текстів, що з'явилися за останні 20 років на літературному ринку: "На прикладі мого брата" Уве Тімма (“Am Beispiel meines Bruders”, 2003), “Траєкторією краба” Гюнтера Грасса (“Im Krebsgang”, 2001), “У нас все гаразд” Арно Гайгера (“Es geht uns gut”, 2005), "Небесні тіла" Тані Дюкерс ("Himmelskörper”, 2003), “Післяродова лихоманка" Сабіне Шіффнер (“Kindbettfieber”, 2005), “Такі ми є” Гілі Люстігер ("So sind wir”, 2005), “Чоловік, що випав зі століття” Морітца Рінке ("Der Mann, der durch das Jahrhundert fiel”, 2010) та ін.

Методологія дослідження. Велика популярність сімейного наративу викликала появу різноманітних жанрових позначень - сімейна хроніка, роман-ріка, роман виховання, роман становлення, сімейна сага, роман поколінь, генераційний роман. 
Це свідчить про постійну зміну жанрових меж, а також безперервний процес їхніх трансформацій відповідно до історико-літературного контексту. Тому доцільно буде застосувати у роботі теорії жанрів М. Бахтіна [4, 5, 6] та А. Фаулера [22].

"Кожна нова робота в жанрі має потенціал змінити цей жанр, або, можливо, навіть викликати появу нового під жанру" [12, с. 142], тобто конвенції жанру змінюються, оскільки його плинних ознак існує набагато більше, ніж стійких. Це пояснюється тим, що змінюються тематика (дитинство, предки, сімейне минуле) та мотиви (блудного сина, сімейної руйнації, спадковості, подорожі/втечі дитини/батька/матері) творів відповідно до змін у політичній та культурній сферах суспільства. У цьому випадку доречно буде сказати, що сімейний роман виступатиме у ролі жанрового канону, як “певна система стійких і твердих жанрових ознак” [11, с. 169]. Жанр сімейного роману сформований історичною традицією, а тому він набув статусу “пам'яті жанру”, який теоретично обгрунтував у своїх дослідженнях М. Бахтін. Учений підкреслює, що при кожній жанровій модифікації висуваються “невмирущі елементи архаїки” [4. с. 178]. При цьому вони постійно модернізуються: “Жанр завжди і той, і не той, завжди і старий, і новий одночасно. Жанр живе сучасним, але завжди пам'ятає своє минуле, свій початок” [4, c. 178]. Таке твердження окреслює розуміння жанру не як системи усталених ознак, а як системи постійних трансформацій.

Для подальшого грунтовного аналізу генераційного роману важливим $\epsilon$ застосування сучасного підходу - нового історизму. Згідно з цим підходом, літературний твір - це не просто перенесення задуму письменника на папір, а певна соціальна та культурна конструкція, створення якої зумовлене не лише авторським задумом, а й конкретним життєвим контекстом. Саме тому генераційні романи - це продукти конкретної епохи. Оскільки змінюється соціальне та культурне середовище, то те, що ми сприймаємо як “текст”, може згодом трансформуватися у “реальність” і навпаки. При цьому надзвичайно важливим $є$ певний історичний момент. Отож, оволодіння соціально-культурним контекстом дає змогу краще зрозуміти твір, у нашому випадку - генераційний роман.

Окрім цього, важливо використати компаративістський метод для співставлення творів сучасних німецькомовних авторів задля виокремлення їхніх спільних рис і визначальних ознак. М. М. Бахтін стверджував, що “текст живе, лише в зіставленні 3 іншим текстом (контекстом). Тільки в точці цього контакту текстів спалахує світло, що освітлює все навколо, долучаючи цей текст до діалогу" [6, с. 120]. Тим самим дослідник наголошував на виокремленні спільного і відмінного в певному контексті творів. У нашому випадку здійснюватиметься порівняльний аналіз сімейного і генераційного романів задля виокремлення їхніх спільних та відмінних рис, оскільки генераційний роман виступатиме як жанровий різновид сімейного роману.

Результати дослідження та їхнс обгрунтування. У літературознавчому дискурсі існує багато думок щодо поняття жанру сімейного роману, оскільки визначити його межі досить проблематично. Окрім цього, активно здійснюється його переосмислення, особливо з огляду на його жанрові критерії. До питання проблеми визначення жанру, жанрових меж і жанрової модифікації зверталися у своїх працях такі літературознавці, як М. М. Бахтін [4, 5, 6], А. Фаулер [22], Т. Бовсунівська [7] та багато інших. Теорію 
класичного сімейного роману висвітлено у наукових розвідках А. Богданова [8] та А. Татьяніної [16].

Зокрема, за словами науковців у класичному сімейному романі важливе смислове навантаження несе взаємодія та взаємовплив представників різних поколінь, які різняться між собою своїм світосприйняттям, думками та духовним досвідом. До визначальних рис класичного сімейного роману можемо віднести такі положення:

1) сімейний роман характеризує детально життя однієї або декількох сімей та подає точний опис їхніх представників;

2) він прагне передати всі особливості людського життя у формах, близьких до реальної дійсності;

3) тут формуються своєрідні композиції, основою яких є найважливіші події в житті людини: весілля, народження дитини, смерть;

4) центром сюжетної побудови й основою конфлікту в сімейному романі $є$ почуття любові та взаємоповаги;

5) головне в сімейному романі - не характери, а стосунки, що визначаються ідеалами [8, с. 308].

Варто зазначити, що однією із ключових ознак сімейного роману є зображення сімейної історії роду, взаємовідносин поміж різними генераціями. Для сімейного роману важливим $є$ створення особливого “колективного героя - сім'ї” [16, с. 71], тобто сім'я у творі виступає головним протагоністом. Також сімейний роман дає поштовх до вирішення проблеми існування “сім'ї як ... інституту” [16, с. 71]. Іншими словами, сімейний роман - це писемна розповідь про життя родини у кількох поколіннях, зображення їхнього побуту і сімейних звичаїв, традицій. Оповідь ведеться від третьої особи, всезнаючого оповідача: “Особливістю наративної форми роману-сімейної хроніки є поєднання двох моделей - генеалогічної моделі, що проходить через зміну поколінь від предків до нащадків, та відтворення сім'ї, стосунки між чоловіком і дружиною, батьками і дітьми” $[15$, с. 227]. Також важливим компонентом жанрової специфіки сімейного роману $є$ зображення побутового часу в лінійній перспективі [18, с. 169].

Попри значну актуальність жанру сімейного роману, все ж існує проблема 3 визначенням його жанрових меж, особливо стосовно інших жанрових різновидів, у нашому випадку генераційного роману. Для того аби краще зрозуміти, де проходить лінія розмежування між цими двома різновидами, варто звернути свою увагу на наукові напрацювання А. Фаулера щодо жанрових трансформацій. Дослідник наголошував на тому, що постійні трансформації всередині одного жанру можуть призводити до виникнення наступного жанрового утворення, яке отримує нове життя у літературному дискурсі. До важливих чинників, які будуть сприяти таким змінам, науковець відносить тематичне оновлення: “Жанрові зміни відбуваються, коли нові теми додаються до їхнього репертуару” [22, с. 233]. Приміром, у класичному сімейному романі мова йтиме про життя однієї або кількох сімей, їхнього побуту та звичаїв. У центрі сюжету завжди постає перед читачем одна 3 найважливіших подій у житті людини - народження, смерть, весілля, а сім'я, як колективний герой, виступатиме головним протагоністом. Головною рисою такого роману стає зображення внутрішньо-сімейного конфлікту та наявних родинних відносин між членами сім'ї: “Основне змістове навантаження 
в сімейному романі несуть взаємодія та взаємовплив представників різних поколінь, типових у своєму світосприйнятті та пошуку ціннісних орієнтирів...” [1, с. 1188].

Важливим моментом у визначенні тематичних особливостей сімейного роману є наявність історичного тла в сюжеті. Проте автори таких творів використовують його лише задля того, щоб показати як історичні події впливають на членів сім’ї та стосунки між ними. Самі історичні факти, події та діячі їм не цікаві. Суттєві зміни в трактуванні історичних подій в сімейних романах відбуваються на зламі XX та XXI століть унаслідок поширення ідей демократії та свободи. Люди все частіше звертаються до власного минулого, минулого своїх родин та цілого народу з метою віднайти себе, свою ідентичність, приналежність до певного простору. Отже, змінюється вектор розвитку класичного сімейного роману як жанру літератури, зокрема основний акцент падає на єдність, неподільність та нерозривність між поколіннями однієї сім”і, “влиття власного “я” у сімейні взаємозв'язки з іншими членами родини” [2, с. 48], а основним принципом побудови роману, за словами дослідниці У. Мерц, стає “розповідь про покоління сім'ї та трактування родинного мікрокосмосу як рушійної сили історичної епохи” [26, с. 43]. Наприклад, у романі “Листи Павла" Моніка Марон подає родинну історію кількох поколінь своєї сім’і, зокрема розповідає про свого дідуся єврея, його насильницьку смерть як результат тоталітарного режиму А. Гітлера. У творі авторка порушує проблему Голокосту та панування націонал-соціалізму у Німеччині, а тема вини та травматичного минулого, немов червона нитка, наскрізь пронизує твір. У генераційному романі Т. Дюкерс "Небесні тіла" також порушується тема спогадів та переборення німецького минулого. Авторка змальовує історію трьох поколінь родини головної героїні Фреї Зандманн, охоплюючи історію життя ії матері, дідуся та бабусі. Усі дії в романі обертаються навколо Другої світової війни, а також трагічної загибелі судна “Вільгельм Густлофф”. У творі представлено кілька поколінь, які мають власні бачення та переконання щодо жахливих історичних подій - хтось замовчує, хтось забуває, а хтось прагне відкрити всі карти та знайти істину.

Культурознавка 3. Льоффлер висловлює свій погляд щодо розвитку генераційного роману, який виникає, на іiі думку, на основі “суперечностей жахливої історії ХХ століття, а саме Другої світової війни та їі наслідків” [25, с. 19]. Тому здебільшого ядро сучасного генераційного роману фокусується на критичних дискусіях між національним минулим та історією націонал-соціалізму. Головною темою таких романів, на думку літературознавки Ф. Айглер, є проблема “вини та відповідальності”, а важливими питаннями постають такі: “Як і внаслідок чого історія сім’ї разом 3 історією нації забувалася, витіснялась чи перекручувалась упродовж кількох поколінь” [20, с. 29].

Ще одним важливим чинником жанрових трансформацій $є$ зміна масштабу сюжету у літературному творі: “Гра з масштабом дозволяє розпоряджатися логічними переходами та призводить до утворення вивершених форм жанру” [7, с. 16]. Зокрема, у класичному сімейному романі мова йде про лінійну дуальну модель сімейних взаємовідносин та конфліктів “батько/син”, “батько/донька”, рідше “мати/донька”. У генераційному романі сюжетна лінія збільшується, і час оповіді охоплює три або більше поколінь у трансформованій ретроспективі: “Нова конструкція сімейного 
роману характеризується важливою ознакою - екзистенційним переплетенням трьох компонентів: індивідуума, сімейної історії та національної історії” [2, с. 22]. У генераційному романі ми спостерігаємо не лише розширення палітри персонажів, а ще й часовий масштаб, який охоплює життя щонайменше трьох поколінь однієї сім'ї. Наприклад, у романі Т. Дюкерс "Небесні тіла" чи У. Тімма "На прикладі мого брата" зображено три покоління однієї сім’ї з власними таємницями та власним минулим, причетним до націонал-соціалізму та Другої світової війни. Важливо те, що автор чи авторка намагаються зрозуміти вчинки, які коїли їхні кровні родичі 50-70 років тому та причини до таких вчинків.

Наступним напрямом трансформації жанру А. Фаулер називає зміну функції тексту. Основним завданням сімейного роману є прагнення передати усі особливості та проблеми сімейного життя, а також вирішити проблему сім'ї як соціального інституту, тому що “сім'я як естетична форма людських взаємовідносин, завжди залишиться моральною опорою становлення особистості людини, перевірки іiї повноцінності” [1, с. 1188]. Окрім цього, сімейні романи можуть адресуватися і присвячуватися реальним нащадкам, що підсилює їхню “дидактико-виховну функцію” [15, с. 226]. У випадку сімейного наративу потрібно звернути увагу на сімейну пам'ять у тексті, яка впливає на самовизначення сім’ї та індивіда.

У генераційному романі ця функція розкривається більш детально. Вона проявляється у зміні призначення та функціонування родинних переказів у сюжеті твору. Головною метою написання поколіннєвих романів $є$ викриття націонал-соціалістичного минулого Німеччини, бажання заглибитись у власну історію та перебороти травми минулого століття. Такі романи містять елементи автобіографічного письма, що тільки підсилює цю функцію, оскільки на прикладах власної сім'ї письменники зачіпають тему переосмислення німецької історії в контексті світової. Окрім цього, автори генераційних романів ставлять перед собою завдання відновити сімейну пам'ять, що криється у щоденниках, фотокартках, документах, зберегти ії та передати наступним поколінням. Адже внаслідок політичного курсу в країні після Другої світової війни усе невимовлене частково зникло. Тому мета відновити спогади у сімейній пам'яті виступає чи не найголовнішим стимулом, що дає поштовх до написання подібних творів.

У романі "На прикладі мого брата" У. Тімм розповідає про свою родину, яка опинилася в центрі бойових дій під час Другої світової війни. На основі знайденого щоденника свого старшого брата автор задається безліччю питань та намагається зрозуміти, чому і як він добровільно вступив у війська СС та підтримував політику націонал-соціалізму. У. Тімм не виправдовував брата, але й не осуджував його, лише намагався по-своєму переосмислити все те, до чого він був причетний.

Яскравим зразком генераційного роману є також роман Гіли Люстігер “Такі ми є”. Авторка, знайшовши листи, фотокартки та іграшкову ляльку серед родинного мотлоху, пише про власну сім'ю - бабусю з дідусем, батьків та саму себе. Головною темою роману є їхнє єврейське походження та забута через складні історичні події історія, яку прагне переосмислити письменниця. На власному прикладі Г. Люстігер демонструє, як забувалась та перекручувалась історія загальнонаціональна, зокрема та, що стосувалась єврейського населення в часи панування А. Гітлера. 
Іншою суттєвою формою оновлення жанрової системи є “включення” позалітературних текстів. Якщо у сімейному романі переважають великі описи сімейно-побутового життя родини, детальне змалювання їхніх відносин, традицій та звичаїв, то у генераційному романі мова йтиме про включення позалітературних текстів, а саме з телебачення, радіо, а також з інших засобів масової інформації. Важливе значення у подібних творах відіграє використання документів, політичних промов, листів та приватних щоденників. Наприклад, у романі У. Тімма "На прикладі мого брата” часто зустрічаються уривки з щоденника, газет чи листів, а також цілі промови офіцерів часів Другої світової війни. А у творі “Листи Павла” Моніки Марон важливе місце мають фотографії, які супроводжують текст від початку до кінця та стають важливим джерелом спогадів для авторки.

Зміна авторського позиціювання також має значення у процесі жанрової трансформації генераційного роману. У сімейному романі автор виступає у ролі оповідача, від третьої особи переповідає текст про родину та іiі членів: “Оповідь у романі ведеться від ... так званого всезнаючого наратора” [15, с. 230]. Це зумовлює певну відстороненість між оповідачем і самою розповіддю про події. Попри це у такій відстороненості “криється мистецький хист у точному виборі деталей, що найповніше характеризують дії і вчинки персонажів” [15, с. 230]. Окрім цього, завдяки відстані наратор може обрати різні позиції: від об'єктивної розповіді до суб'єктивної, тобто передавання думок головних героїв.

У генераційному романі присутні елементи автобіографічного письма, які переплітаються з фікцією, а оповідь ведеться від імені першої особи, яка і виступатиме головним героєм у романі. Пояснити, інтерпретувати та переосмислити історичне минуле свого народу намагається друге й третє покоління німецьких письменників. Це ті покоління, які не є очевидцями воєн XX століття, але які прагнуть не втратити 3в'язок з попередніми генераціями [17, с. 552], адже приналежність німецькомовних письменників до різних поколінь проявляється у відмінних поглядах на пережите, зокрема, на Другу світову війну та націонал-соціалістичне минуле Німеччини. Так, Уве Тімм та Моніка Марон - представники покоління 68, а Таня Дюкерс чи Арно Гайгер - покоління 89 року. Кожна $з$ цих генерацій усвідомлює по-своєму виклик історії та прагне переосмислити найсумніші її сторінки, опираючись на власний досвід та переконання. Відтак, можна стверджувати, що покоління 68-го дало початок демократичним ідеям у німецькому суспільстві. Молода генерація прагнула мобілізуватися в рішучій битві проти імперіалізму та фашизму, а також, засуджуючи попереднє покоління, викривати нові підходи до переосмислення нацистського минулого. Для покоління внуків, або як його ще називають, покоління 89-го року “минуле залишалось чимось особисто не пережитим”, проте часова дистанція, яка виникла між нацистською епохою і кінцем століття відкрила нову перспективу і дозволила “молодим письменникам сказати своє слово в переосмисленні важких моментів національної історії” [21], а також тверезо й об'єктивно вирішити цю проблему.

3 елементами системи трансформації жанру працювала також літературознавка Н. Копистянська. Вона зазначала, що “існує тісний, причому двобічний зв’язок між 
становленням методу і виникненням жанрових модифікацій” [10, с. 242]. Науковиця аргументує свою думку так: “В проблему жанрової модифікації входять і такі питання, як роль публіцистичної діяльності письменника в його творчості, новий тип соціальності в літературі, усвідомлення в ній народності й героїчного, питання історизму, співвідношення об'єктивного й суб'єктивного” [10, с. 246]. Отож, жанрові модифікації утворюються у зв'язку з істотними змінами у світогляді суспільства.

Сім'я, як первинний осередок суспільства і як структура з важливими соціальними функціями, має важливе значення в житті кожного 3 нас. Надмірна увага до цього феномену призводить до того, що у літературознавчому просторі тема сім’ї посідає одне з чільних місць. Розквіт сімейного роману, що припадає на кін. XIX - поч. XX ст., зумовлений кризою інститутів сім’ї та шлюбу у Свропі. Сучасний генераційний роман, що виникає на кін. XX - поч. XXI ст., передусім стосується німецької нації, для якої тема спогадів та замовчування злочинів минулого століття $є$ й до сьогодні актуальною й досліджуваною. Великий інтерес до історії держави, що тематично розкривається у генераційних романах, спостерігається після падіння Берлінської стіни та об'єднання Німеччини. У коло дискусій потрапляє не лише “історичний аспект XX ст., а й сам процес пригадування" [20, с. 19].

Наслідки Другої світової війни переосмислюються в багатьох монографіях та наукових дослідженнях. Існують думки, що тема історичного минулого Німеччини залишається до сьогодні ще негласно табуйованою [17, с. 552]. На початку XXI ст. не лише Німеччину, але й цілий світ охопила хвиля спогадів. А минуле, від якого ми все більше віддаляємось, продовжує впливати на сучасні покоління, які пропонують його нове прочитання. Це відповідно призводить до актуальності такого поняття, як “комунікативна пам'ять” поколінь. На думку А. Ассманн, така пам’ять існує протягом життя трьох поколінь: діти - батьки - діди і триває 80 - 100 років. У цьому випадку мають місце спогади, що формуються очевидцями тієї чи іншої події на підставі їхньої біографії, власного досвіду та комунікації, і яка триває, як вже зазначалося, лише впродовж життя наступних трьох-чотирьох поколінь. У творі пам'ять поколінь найкраще розкривається на прикладі сім’ї.

Жанрові трансформації так чи інакше пов'язані з ідеологічними процесами свого часу. Треба мати на увазі і той факт, що для успішного впливу на жанрову трансформацію ідеологія повинна стати частиною світогляду письменника.

Отож, можемо стверджувати, що усі вищенаведені прояви жанрової трансформації сімейного роману призводять до появи нової “структурованої системи художнього мислення” [7, с. 27] - а саме генераційного роману. Для кращого розуміння відповідних трансформаційних процесів відтворимо наші спостереження у табл. 1. 
Жанрові трансформації сімейного роману

Таблиия 1

(на прикладі новітньої німецькомовної літератури)

\begin{tabular}{|c|c|c|}
\hline Сімейний роман & $\begin{array}{c}\text { Прояви } \\
\text { жанрової } \\
\text { трансформації }\end{array}$ & Генераційний роман \\
\hline $\begin{array}{l}\text { Зображено історію сімейного роду, } \\
\text { родинний побут, традиції, звичаї. } \\
\text { Основою сюжетної композиції є } \\
\text { найважливіші події в житті людини: } \\
\text { весілля, народження дитини, } \\
\text { смерть. } \\
\text { Історичне тло в романі присутнє, } \\
\text { але його основна функція полягає } \\
\text { у зображенні впливу історичних } \\
\text { подій на сім'ю, її членів та } \\
\text { стосунки між ними. }\end{array}$ & $\begin{array}{l}\text { Тематичне } \\
\text { оновлення }\end{array}$ & $\begin{array}{l}\text { Стрижневою постає тема сімейних } \\
\text { спогадів та збереження пам’яті } \\
\text { предків, переборення народом } \\
\text { Німеччини травматичного минулого, } \\
\text { зумовленого Другою світовою } \\
\text { війною та пануванням націонал- } \\
\text { соціалістичного режиму і його } \\
\text { наслідків. }\end{array}$ \\
\hline $\begin{array}{l}\text { Зображено модель сімейних } \\
\text { взаємовідносин та конфліктів на } \\
\text { кшталт батько/син, батько/донька, } \\
\text { мати/донька, батьки/діти. }\end{array}$ & $\begin{array}{l}\text { “Зміна } \\
\text { масштабу } \\
\text { твору”" }\end{array}$ & $\begin{array}{l}\text { Збільшується не лише кількість } \\
\text { персонажів, а й час оповіді, який } \\
\text { охоплює три або більше поколінь } \\
\text { однієї сім’ї у трансформованій } \\
\text { ретроспективі. }\end{array}$ \\
\hline $\begin{array}{l}\text { Основним завданням є прагнення } \\
\text { передати всі особливості } \\
\text { людського життя у формах, } \\
\text { близьких до реальної дійсності, } \\
\text { розглянути проблему існування } \\
\text { сім’ї як соціального інституту, в } \\
\text { якому формується особистість, а } \\
\text { також зберегти сімейну пам’ять } \\
\text { для самовизначення сім'ї та } \\
\text { індивідуума. }\end{array}$ & $\begin{array}{l}\text { "Зміна } \\
\text { функції } \\
\text { тексту" }\end{array}$ & $\begin{array}{l}\text { Головною метою є переосмислення } \\
\text { націонал-соціалістичного минулого } \\
\text { Німеччини крізь призму інституту } \\
\text { сім’ї з кількох поколінь, бажання } \\
\text { заглибитись у власну історію, } \\
\text { перебороти травми минулого } \\
\text { століття, відновити і зберегти у } \\
\text { пам’яті завдяки письму та літературі } \\
\text { все, що колись забувалось і } \\
\text { витіснялось. }\end{array}$ \\
\hline $\begin{array}{l}\text { Характеризується детально життя } \\
\text { одного або декількох поколінь та } \\
\text { змальовуваються їхні представники. } \\
\text { У тексті переважають великі } \\
\text { описи сімейно-побутового життя, } \\
\text { відносин членів родини, їхніх } \\
\text { традицій. }\end{array}$ & \begin{tabular}{|c|} 
"Включення" \\
позалітератур- \\
них текстів
\end{tabular} & $\begin{array}{l}\text { Активне включення позалітературних } \\
\text { текстів: з архівів телебачення, радіо, } \\
\text { з інших засобів масової інформації. } \\
\text { Важливе значення відіграє } \\
\text { використання текстів/документів, } \\
\text { політичних промов, листів та } \\
\text { приватних щоденників, фотографій. }\end{array}$ \\
\hline $\begin{array}{l}\text { Оповідь ведеться від третьої особи, } \\
\text { всезнаючого оповідача, який може } \\
\text { відсторонено вести об’єктивну } \\
\text { розповідь про життя сім’ї або ж } \\
\text { суб’єктивно передавати думки } \\
\text { головних героїв. }\end{array}$ & $\begin{array}{c}\text { Зміна } \\
\text { авторського } \\
\text { позиціювання }\end{array}$ & $\begin{array}{l}\text { Оповідь ведеться від першої особи } \\
\text { - головного героя роману, який } \\
\text { перебрав на себе завдання пояснити, } \\
\text { інтерпретувати та переосмислити, на } \\
\text { прикладі власних сімейних життпписів, } \\
\text { історичне минуле свого народу, } \\
\text { відновити сімейну пам’ять й таким } \\
\text { чином віднайти свою ідентичність. } \\
\end{array}$ \\
\hline $\begin{array}{l}\text { Виникнення та популяризація } \\
\text { сімейного роману кін. ХІХ - поч. } \\
\text { ХХ ст. обумовлена соціокультурною } \\
\text { кризою інститутів сім’ї та шлюбу в } \\
\text { Європі. }\end{array}$ & $\begin{array}{c}\text { Зміна } \\
\text { світогляду у } \\
\text { суспільстві }\end{array}$ & $\begin{array}{l}\text { Особливий інтерес до історії } \\
\text { держави, що тематично розкривається } \\
\text { у романах, спостерігається після } \\
\text { падіння Берлінської стіни та } \\
\text { об'єднання Німеччини. }\end{array}$ \\
\hline
\end{tabular}


Висновки. Будь-яка зміна форм у літературі відбувається у вигляді узгодження певних трансформацій та їхнього системного осмислення, які об'єднуються в єдине, утворюючи модифікацію, яка й претендує на статус жанру. Так зароджується у новітній німецькомовній літературі генераційний роман - різновид класичного сімейного роману. Можна стверджувати, що одностайності в диференціації понять сімейний та генераційний роман немає. Проте однозначно те, що першоосновою для створення генераційного роману слугує сімейний роман, який виступає в ролі “пам'яті жанру” та його основним підгрунтям. У німецькомовному просторі розвиток сімейного наративу протягом XX-XXI ст. характеризується певною національною специфікою. Найважливішим критерієм, який виокремлює саме німецькомовний генераційний роман 3-поміж інших - це його функція та завдання.

Після 1945-го року у Німеччині люди намагалися не згадувати минуле і всілякими способами стерти з пам'яті все, що коїлося в країні під час війни та злочинного режиму А. Гітлера. Політичний курс “замовчування минулого”, введений західним канцлером ФРН К. Аденауером одразу після війни пронісся через усю країну. Саме це призвело, за словами Е. Єссе, до “самокритичної свідомості у більшої частини населення" [24, c. 13], адже не всі одразу прийняли те, що їхні батьки, діди та бабусі чи інші родичі були причетними до тієї жорстокості, яку заподіяв диктаторський режим та вчиняли важкі злочини проти життя та свободи інших громадян держави. Проте так чи інакше травми минулого давали знати про себе у родинних спогадах німецьких сімей. Влучними у даному випадку будуть слова Ніцше, на які неодноразово покликається А. Ассманн і які, на iї думку, найкраще виголошують основну проблему німецькомовного генераційного роману: “... оскільки ми повинні бути плодами попередніх поколінь, то в цей же час ми стаємо результатом їхніх пристрастей, помилок та злочинів, що унеможливлює звільнення з цього ланцюга. Якщо ми навіть засуджуємо ці помилки і вважаємо себе не причетними до них, то ми $€$ не в змозі заперечити той факт, що ми пов'язані з нашим походженням" [3]. Іншими словами, як би ми цього не хотіли, ми є частиною історії національної та сімейної, яку генераційний роман "продовжує, переписує і повертає у майбутне" [3].

Отже, можна стверджувати, що у художніх текстах новітньої німецькомовної літератури робота 3 сімейною пам'яттю, травматичним минулим, переосмисленням колективної вини та відповідальності попередніх поколінь переходять на новий рівень. У Німеччині на сьогоднішній день сформована культура пам'яті, яка грунтується на тому, що забуття не приведе народ до визволення від відповідальності за Голокост та причетність до націонал-соціалістичного режиму. Саме тому категорія пам'яті посідає центральне місце в німецькому суспільстві й асоціюється переважно з етичним обов'язком. Письменники другого і третього повоєнного покоління беруться за це завдання і наближаються до історії своїх предків настільки, наскільки це можливо, а генераційні романи стають простором для відновлення та збереження пам'яті про власне минуле. 


\section{СПИСОК ВИКОРИСТАНОЇ ЛІТЕРАТУРИ}

1. Алламуратова А. К вопросу о жанре семейного романа / А. Алламуратова, Г. Алламуратова // Молодой учёный / А. Алламуратова, Г. Алламуратова. - Казань, 2014. - (Филология; вип. 4). - С. 1187-1189.

2. Ассманн А. Длинная тень прошлого. Мемо-риальная культура и историческая политика / Ассманн Алайда - Москва : Новое литературное обозрение, 2014. - 328 с.

3. Ассманн А. Забвение истории - одержимость историей [Электронный ресурс] / А. Ассманн // Новое Литературное Обозрение. - 2019. - Режим доступа : https://books. google.com.ua/books?id=gsO4DwAAQBAJ\&printsec=frontcover\&dq=Aссман+забвени e+истории\&hl=ru\&sa=X\&ved=0ahUKEwiu2fCXzYrmAhWLfFAKHT7TD7MQ6AEIN $\mathrm{DAB} \# \mathrm{v}=$ onepage $\& \mathrm{q} \& \mathrm{f}=$ false

4. Бахтин М. Вопросы литературы и эстетики / М. Бахтин — Москва : Художественная Литература, 1975. - 500 с.

5. Бахтин М. Формы времени и хронотопа в романе Очерки по исторической поэтике [Электронный ресурс] / М. Бахтин. - Режим доступа : http://philologos.narod.ru/ bakhtin/hronotop/hronmain.html

6. Бахтин М. М. Автор и герой: К философским основам гуманитарных наук / М. М. Бахтин. - Москва : Азбука, 2000. - 334 с

7. Бовсунівська Т. Жанрові модифікації сучасного роману / Т. Бовсунівська. - Харків : Діса плюс, 2015. - 368 с.

8. Богданов А. Н. Литературные роды и виды / А. Н. Богданов // Теория литературы в связи с проблемами эстетики. - М. : Просвещение. 1970. - С. 307-310

9. Завягина М. Тансформация жанров в русской прозе конца XX века : дис. докт. філ. наук : 10.01.01 / М. Завягина. - Астрахань, 2001. - 356 с.

10. Копыстянская Н. Ф. Жанровые модификации в чешской литературе / Н. Копыстянская - Львов : Вища школа, 1978. - 258 с.

11. Кушнірова Т. Жанр як структурована категорія сучасного літературознавства / Т. Кушнірова // Наукові записки ХНПУ ім. Г. Сковороди. - Харків : ППВ “Нове слово", 2010. - Вип. 1(61). - Ч. 2. - С. 168-175.

12. Коваленко Д. Процеси жанрової дифузії та диференціації в сучасному українському романі / Д. Коваленко // Науковий вісник Ужгородського університету. - Ужгород, 2016. - (Філологія; вип. 2) - С. 142- 147.

13. Покидько Г. Модифікація жанру сімейного роману в творчості Енн Тайлер : дис. канд. філ. наук : 10.01.04 / Г. Покидько. - Київ, 2007. - 231 с.

14. Порохняк Н. Роман-сімейна хроніка та сімейний наратив (інтертекстуальне прочитання) / Н. Порохняк // Волинь філологічна: текст і контекст. - 2009. Вип. 7. - С. 222-230. - Режим доступу : http://nbuv.gov.ua/UJRN/Vftk_2009_7_27

15. Порохняк Н. Формування жанрових ознак роману-сімейної хроніки під впливом сімейного наративу як універсального тексту культури : (на матеріалі “Саги про Форсайтів” Дж. Голсуорсі) / Н. Порохняк // Studia Methodologica : альманах / упоряд. І. В. Папуша. - Тернопіль : ТНПУ, 2008. - Вип. 24 : Новітня теорія літератури і проблеми літературної антропології. - С. 225-231.

16. Татьянина А. Проза молодого Толстого и проблема семейного романа : дис. канд. філ. наук : 10.01.01 / А. Татьянина - Москва, 2000. - 214 с.

17. Третевич М. Концептуалізація історичної пам'яті в романі Уве Тімма "На прикладі мого брата" / М. Третевич // Сучасні літературознавчі студії. Літературний дискурс: транскультурні виміри. - 2015. - №12. - С. 550-559. 
18. Чик Д. Ex providentia majōrum: жанровий різновид сімейного роману-хроніки в англійській та українській літературі I-ї половини XIX ст. / Д. Чик // Наукові записки Бердянського державного педагогічного університету. - 2014. - С. 165-175. 19. Assmann A. Unbewältigte Erbschaften. Fakten und Fiktion in zeitgenössischen Familienroman / A. Assmann // Generationen: Erfahrung - Erzählung - Identität / Assmann. Konstanz : UVK, 2009. - S. 49-69

20. Eigler F. Gedächtnis und Geschichte in Generationenromanen seit der Wende / F. Eigler. Berlin : Erich Schmidt Verlag, 2005. - 259 S.

21. Dückers T. Spuren suchen. "Fehlt" die NS-Zeit in den Romanen der "Enkelgeneration"? / T. Dückers. // In: Edit: Papier für neue Texte. - 2002. - № 29. - S. 53-56.

22. Fowler A. Transformantion of Genre / A. Fowler // Modern Genre Theory. - New York : Pearson Education, 2000. - S. 232-249.

23. Jahn B. Familienkonstruktionen. Zum Problem des Zusammenhangs der Generationen im aktuellen Familienroman / B. Jahn // Zeitschrift für Germanistik - Berlin, 2006. - S. 581596.

24. Jesse E. Doppelte Vergangenheitsbewältigung in Deutschland / E. Jesse // Vergangenheitsbewältigung. - Berlin : Duncker \& Humblot, 1997. - S. 11-26.

25. Löffel S. Die Familie. Ein Roman / L. Sigrid // Literaturen. - 2005. - № 6. - S. 17-26.

26. März U. Erforschen oder Nacherzählen [Электронный pecypc] / U. März // Die Zeit. 2003. - Zugriffsmodus : /www.zeit.de/2003/19/L-Wackwitz_2fWerle

27. McKeon M. Generic Transformation and Social Change: Rethinking the Rise of the Novel / M. McKeon // Theory of the Novel: a Historical Approach. - London : The Johns Hopkins University Press, 2000. - S. 382-399.

28. Neuschäfer M. Das bedingte Selbst. Familie, Identität und Geschichte im zeitgenössischen Generationenroman / M. Neuschäfer. - Berlin : Epubli GmBH, 2013. - 449 s.

29. Weigel S. Genea-Logik. Generation, Tradition und Evolution zwischen Kultur- und Naturwissenschaften / S. Weigel. - München : Verlag Wilhelm Fink, 2006. - 288 s.

\section{СПИСОК ВИКОРИСТАНИХ ДЖЕРЕЛ}

30. Тімм У. На примере брата [Электронный ресурс] / Уве Тімм - Режим доступа : https:// www.e-reading.club/bookreader.php/1033320/Timm_-_Na_primere_brata.html.

31. Dückers T. Himmelskörper / T. Dückers. - Berlin : Aufbau, 2004. $-\overline{3} 19 \mathrm{~s}$.

32. Geiger A. Es geht uns gut / A. Geiger. - München : Btv, 2007. -390 s.

33. Lustiger G. So sind wir / G. Lustiger. - Berlin : eBook Berlin Verlag, 2015. - 272 s.

34. Maron M. Pawels Briefe / M. Maron. - Frankfurt a. M. : FIischer Taschenbuch Verlag, 2001. - $205 \mathrm{~s}$.

\section{REFERENCES}

1. Allamuratova A. K voprosu o zhanre semejnogo romana / A. Allamuratova, G. Allamuratova // Molodoj uchjonyj / A. Allamuratova, G. Allamuratova. - Kazan', 2014. - (Filologija; vip. 4). - S. 1187-1189.

2. Assman, A. Dlinnaya ten proshlogo. Memorialnaya kultura i istoricheskaya politika / A. Assmann ; [per. s nem ]. Moskva : Novoe literaturnoe obozrenie, 2014. - $328 \mathrm{~s}$.

3. Assmann A. Zabvenie istorii - oderzhimost' istoriej [Elektronnij resurs] / Assmann // Novoe Literaturnoe Obozrenie. - 2019. - Rezhym dostupa : https://books.google.com.ua/bo oks? id=gsO4DwAAQBAJ\&printsec=frontcover\&dq=Aссман+забвение+истории\&hl=ru 
$\&$ sa $=$ X\&ved $=0$ ahUKEwiu2fCXzYrmAhWLfFAKHT7TD7MQ6AEINDAB\#v $=$ onepage \& $\mathrm{q} \& \mathrm{f}=$ false

4. Bahtin M. Voprosy literatury i jestetiki / M. Bahtin. - Moskva : Hudoyhestvennaja literatura, 1975. - $500 \mathrm{~s}$.

5. Bahtin M. Formy vremeni i hronotopa $\mathrm{v}$ romane Ocherki po istoricheskoj pojetike [Elektronnij resurs] / M. Bahtin - Rezhym dostupa : http://philologos.narod.ru/bakhtin/hronotop/ hronmain.html

6. Bahtin M. M. Avtor i geroj: K filosofskim osnovam gumanitarnyh nauk / M. M. Bahtin. Moskva: Azbuka, 2000. - 334 s.

7. Bovsunivska T. Zhanrovi modyfikatsii suchasnoho romanu / T. Bovsunivska. - Kharkiv : Disa plius, 2015. - $368 \mathrm{~s}$.

8. Bogdanov A.N. Literaturnye rody i vidy / A. N. Bogdanov // Teorija literatury v svjazi s problemami jestetiki. - M. : Prosveshhenie. 1970. - S. 307-310.

9. Zavjagina M. Tansformacija zhanrov v russkoj proze konca HH veka : dis. dokt. fil. nauk : 10.01.01 / M. Zavjagina. - Astrahan', 2001. - $356 \mathrm{~s}$.

10. Kopistjanskaja N.F. Zhanrovye modifikacii v cheshskoj literature / N. Kopistjanskaja L'vov: Vishha shkola, 1978. - S. 258.

11. Kushnirova T. Zhanr yak strukturovana katehoriia suchasnoho literaturoznavstva / T. Kushnirova // Naukovi zapysky KhNPU im. H. Skovorody. - Kharkiv : PPV "Nove slovo", 2010. - Vyp. 1(61). - Ch. 2. - S. 168-175.

12. Kovalenko D. Protsesy zhanrovoi dyfuzii ta dyferentsiatsii v suchasnomu ukrainskomu romani / D. Kovalenko // Naukovyi visnyk Uzhhorodskoho universytetu. - Uzhhorod, 2016. - (Filolohiia; vyp. 2). - S. 142- 147.

13. Pokydko H. Modyfikatsiia zhanru simeinoho romanu v tvorchosti Enn Tailer : dys. kand. fil. nauk : 10.01.04 / H. Pokydko. - Kyiv, 2007. - $231 \mathrm{~s}$.

14. Porokhniak N. Roman-simeina khronika ta simeinyi naratyv (intertekstualne prochytannia) / N. Porokhniak // Volyn filolohichna: tekst i kontekst. - 2009. - Vyp. 7. - S. 222-230. Rezhym dostupu: http://nbuv.gov.ua/UJRN/Vftk 2009727

15. Porokhniak N. Formuvannia zhanrovykh oznak romanu-simeinoi khroniky pid vplyvom simeinoho naratyvu yak universalnoho tekstu kultury : (na materiali "Sahy pro Forsaitiv" Dzh. Holsuorsi) / N. Porokhniak // Studia Methodologica : almanakh / uporiad. I. V. Papusha. - Ternopil : TNPU, 2008. - Vyp. 24 : Novitnia teoriia literatury i problemy literaturnoi antropolohii. - S. 225-231.

16. Tat'janina A. Proza molodogo Tolstogo i problema semejnogo romana : dis. kand. fil. nauk : 10.01.01 / A. Tat'janina. - Moskva, 2000. - $214 \mathrm{~s}$.

17. Tretevych M. Kontseptualizatsiia istorychnoi pamiati v romani Uve Timma "Na prykladi moho brata" / M. Tretevych // Suchasni literaturoznavchi studii. Literaturnyi dyskurs: transkulturni vymiry. - 2015. - №12. - S. 550-559.

18. Chyk D. Ex providentia majōrum: zhanrovyj riznovyd simejnogho romanu-khroniky v anghlijsjkij ta ukrajinsjkij literaturi I-ji polovyny KhIKh st. / D. Chyk // Naukovi zapysky Berdjansjkogho derzhavnogho pedaghoghichnogho universytetu. - 2014. - S. 165-175.

19. Assmann A. Unbewältigte Erbschaften. Fakten und Fiktion in zeitgenössischen Fami-lienroman / A. Assmann // Generationen: Erfahrung - Erzählung - Identität / Assmann. - Konstanz : UVK, 2009. - S. 49-69

20. Eigler F. Gedächtnis und Geschichte in Generationenromanen seit der Wende / F. Eigler. Berlin : Erich Schmidt Verlag, 2005. - 259 S.

21. Dückers T. Spuren suchen. "Fehlt" die NS-Zeit in den Romanen der "Enkelgeneration"? / T. Dückers. // In: Edit: Papier für neue Texte. - 2002. - № 29. - S. 53-56. 
22. Fowler A. Transformantion of Genre / A. Fowler // Modern Genre Theory. - New York : Pearson Education, 2000. - S. 232-249.

23. Jahn B. Familienkonstruktionen. Zum Problem des Zusammenhangs der Generationen im aktuellen Familienroman / B. Jahn // Zeitschrift für Germanistik - Berlin, 2006. - S. 581596.

24. Jesse E. Doppelte Vergangenheitsbewältigung in Deutschland / E. Jesse // Vergangenheitsbewältigung. - Berlin : Duncker \& Humblot, 1997. - S. 11-26.

25. Löffel S. Die Familie. Ein Roman / L. Sigrid // Literaturen. - 2005. - № 6. - S. 17-26.

26. März U. Erforschen oder Nacherzählen [Электронный pecypc] / U. März // Die Zeit. 2003. - Zugriffsmodus : /www.zeit.de/2003/19/L-Wackwitz_2fWerle

27. McKeon M. Generic Transformation and Social Change: Rethinking the Rise of the Novel/ M. McKeon // Theory of the Novel: a Historical Approach. - London : The Johns Hopkins University Press, 2000. - S. 382-399.

28. Neuschäfer M. Das bedingte Selbst. Familie, Identität und Geschichte im zeitgenössischen Generationenroman / M. Neuschäfer. - Berlin : Epubli GmBH, 2013. - 449 s.

29. Weigel S. Genea-Logik. Generation, Tradition und Evolution zwischen Kultur- und Naturwissenschaften / S. Weigel. - München : Verlag Wilhelm Fink, 2006. - 288 s.

\title{
SOURCES
}

30. Timm U. Na primere brata [Elektronnyi resurs] / Uve Timm. - Rezhym dostupa : https:// www.e-reading.club/bookreader.php/1033320/Timm_-_Na_primere_brata.html.

31. Dückers T. Himmelskörper / T. Dückers. - Berlin : Aufbau, 2004. $-\overline{3} 19$ s.

32. Geiger A. Es geht uns gut / A. Geiger. - München : Dtv, 2007. - 390 s.

33. Lustiger G. So sind wir / G. Lustiger. - Berlin : eBook Berlin Verlag, 2015. - 272 s.

34. Maron M. Pawels Briefe / M. Maron. - Frankfurt a. M. : FIischer Taschenbuch Verlag, 2001. $-205 \mathrm{~s}$.

\section{THE GENERATIONAL NOVEL AS A GENRE VARIETY OF THE FAMILY NOVEL}

\section{Olya Hrecheshnyuk}

\author{
Ivan Franko National University of Lviv, \\ 1, Universytetska Str., Lviv, Ukraine, 79000 \\ e-mail:hrecheshnyukolya@i.ua
}

The article deals with the problem of definition of the generational novel as a genre subtype of the family novel by the example of modern German literature. At the beginning of the 21 st century, the question about the nature of a generational novel as a specific type of the family novel has been mostly discussed among specialists in literature studies. A striving to reinterpret the traumatic past of the 20th century provoke modern German-speaking writers, representatives of the second and third post-war generation, to search for their identity and to reveal the blank spots in the forgotten history of their own family and the whole 
country. Appreciating the great popularity of this genre, Western European specialists in literature are actively engaged in research on various aspects of the generation novel (discourse of memory and history in the novel - F. Eigler, G. Welzer, R. Pokrywka, A. Assmann; the role of writers' generations - M. Neuschäfer, N. Leongard; the structure of the narrative in the novel - E. Agazzi, S. Costalgi, M. Galli; the problem of the family - W. Wintersteiner, A. Eichenberg, Y. Freytag, S. Löffler and others ). The article shows the significance of the newly created genre of literature and the reasons of its forming in the German-speaking society. The research demonstrates the important conditions of genre transformation of the classic family novel, which lead to the emergence of a new literary phenomenon. The results of the research show that the change of the form in the literature exists as an agreement of the genre conversion and sociocultural context and their systemic understanding that work together and create a new genre variety. The methodology used in this paper is based on the works of M. Bakhtin and A. Fowler, who both dealt with genre theory. The study also makes use of important papers of recognized scholars (M. Bakhtin, A. Fowler, A. Assmann, S. Weigel, N. Kopystyanska and others). Despite the importance of the generational novel, it has been analyzed only on a limited scale, this gap having motivated the present research.

Key words: family, generational novel, family novel, genre, genre variety, genre transformation. 